\title{
Intercropping of collard green and radish 'Cometo': spatial arrangement and growing efficiency
}

\author{
Marcelo de Sousa Pinheiro ${ }^{*} \mathbb{D}$, Jéssica Soares Pereira ${ }^{l}$, Cristiane Ramos Coutinho ${ }^{l}$, \\ Rosenya Michely Cintra Filgueiras ${ }^{1}$, Marcelo de Almeida Guimarães ${ }^{1}$, Rosilene Oliveira Mesquita ${ }^{l}$
}

$10.1590 / 0034-737 X 201966040001$

\begin{abstract}
Intercropping is a method of growing plants that assists in rational use of natural resources. Based on this concept, the aim of this study was to evaluate the response of collard green and radish 'Cometo' crops in monoculture and in intercropping under different spatial arrangements through physical production indicators (technical coefficients). The study was conducted in plant beds in a randomized block design (RBD) with 5 treatments and 4 replications. The treatments involved growing the two crops separately and intercropped under different spatial arrangements: (1:2) one row of radish 'Cometo' between two rows of collard green; (2:2) two rows of radish 'Cometo' between two rows of collard green; and (3:2) three rows of radish 'Cometo' between two rows of collard green. The spatial arrangements adopted did not affect the growth and development of radish 'Cometo' and of collard green, and all the arrangements used exhibited high land use efficiency, especially the 3:2 arrangement, which provided the greatest land use efficiency, at 1.69.
\end{abstract}

Keywords: Raphanus sativus; Brassica oleracea L. var. acephala; photosynthetic rate; land equivalent ratio.

\section{INTRODUCTION}

Cropping practices adopted in traditional agriculture have caused considerable damage to soil, the environment, and soil organisms when carried out in an inadequate manner, especially when there is combined action from various causes, which accelerates the process of ecosystem degradation (Oliveira et al., 2010).

However, there are age-old cropping practices that have allowed development of agriculture that is more sustainable and less aggressive to the environment. Cultivation of multiple crops simultaneously in the same area, known as intercropping, is noteworthy in this respect. According to Lithourgidis et al. (2011), intercropping has been practiced for centuries, especially in tropical regions in small plots under subsistence agriculture.
Intercropping is a method that can assist in rational use of natural resources for food production, with less environmental impact and greater profitability (Rezende, 2008). When performed correctly, it can promote an increase in yield, and may also limit pests and diseases ( $\mathrm{Li}$ et al., 2009). According to Lin et al. (2014), intercropping has also been shown to be an effective remedial measure for contamination of agricultural land by heavy metals, such as cadmium.

The efficiency of intercropping directly depends on the growing system and on the crops involved, and there is the need for complementarity between them (Resende \& Vidal, 2008). Rezende et al. (2006) furthermore add that this practice can provide greater gain in production to producers through the synergistic or compensatory effect of one crop on another. They see it as an accessible

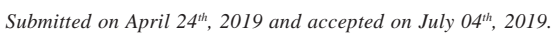

${ }^{1}$ Universidade Federal do Ceará, Departamento de Fitotecnia, Fortaleza, Ceará, Brasil.marcelospufc@gmail.com; jessicasoaresp99@gmail.com; cris.ramos@yahoo.com.br; rosenya_michelycf@hotmail.com; mguimara@ufc.br; rosilenemesquita@gmail.com
}

*Corresponding author: marcelospufc@gmail.com 
technology that is easily applied and that has come to constitute an alternative cropping system.

Nevertheless, for intercropping to be efficient and offer good dividends to the producer and to the environment, the composition of species and spatial arrangements used for the crops must be studied in advance. Such factors are important for management and can be employed with the aim of improving use of resources and the efficiency of intercropping in vegetable crops (Favacho, 2015). According to Camili et al. (2013), the aim is to seek for species that allow good interspecific combining ability and, consequently, greater production and agroeconomic efficiency in intercropping systems.

Although intercropping of different species provides various benefits and various species have been associated, studies are lacking on the viability of associating collard green (Brassica oleracea var. acephala L.) and radish 'Cometo' (Raphanus sativus L.). Both belong to the same family (Brassicaceae), but their different size, crop cycles, and nutrient demands can favor optimization of the space dedicated to them, which can generate increases in producer income.

On this basis, the aim of this study was to evaluate the response of collard green and radish 'Cometo' crops in monoculture and in intercropping under different spatial arrangements through physical production indicators (technical coefficients).

\section{MATERIAL AND METHODS}

The study was developed in the didactic vegetable garden belonging to the Plant Science Department of the Universidade Federal do Ceará (UFC), Pici campus, in the municipality of Fortaleza, CE, Brazil, at $3^{\circ} 36^{\prime}$ S, $37^{\circ} 48^{\prime} \mathrm{W}$. Altitude is approximately $19.5 \mathrm{~m}$ above sea level. The predominant climate in the region according to the Köppen classification is Aw', rainy tropical.

A randomized block experimental design (RBD) was used with 5 treatments and 4 replications. The treatments consisted of separate cultivation of collard green (T1) and radish 'Cometo' (T2) crops, as well as intercropping them under different spatial arrangements: (1:2) one row of radish 'Cometo' between two rows of collard green (T3); (2:2) two rows of radish 'Cometo' between two rows of collard green (T4); and (3:2) three rows of radish 'Cometo' between two rows of collard green (T5). The spatial arrangements were performed in such a way as to distribute the intercropped plants within the same area that would be occupied by monoculture of collard green; only the planting density and arrangement of radish 'Cometo' was changed. radish 'Cometo' was considered the secondary crop in the intercropping.
The following spacings were used for each treatment: $\mathrm{T} 1-0.50 \mathrm{~m}$ between plants and $0.80 \mathrm{~m}$ between crop rows; $\mathrm{T} 2-0.20 \mathrm{~m}$ between plants and $0.20 \mathrm{~m}$ between crop rows; $\mathrm{T} 3$, T4, and T5 - the collard green plants remained at a spacing of $0.50 \times 0.80 \mathrm{~m}$, but the radish 'Cometo' plants were placed between the collard green. The following treatments were used in intercropping: T3 - consisted of 0.25 m between the radish 'Cometo' crop row and the collard green crop rows, and $0.20 \mathrm{~m}$ between radish 'Cometo' plants in the crop row; $\mathrm{T} 4-0.16 \mathrm{~m}$ between the radish 'Cometo' crop rows and the collard green crop rows and $0.20 \mathrm{~m}$ between radish 'Cometo' plants in the crop row; T5 - 0.12 $\mathrm{m}$ between the radish 'Cometo' crop rows and the collard green crop rows and $0.20 \mathrm{~m}$ between radish 'Cometo' plants in the crop row.

The experiment was carried out in plant beds with dimensions of $1.0 \mathrm{~m}$ width and $10.0 \mathrm{~m}$ length. To establish the crops, the area was cleared to eliminate weeds, and the soil was turned over to a depth of $0.20 \mathrm{~m}$. The plant beds received nutrient supplementation through addition of organic compost plus application of goat manure and chicken litter in the proportion of 3:1. The fertility of the soil used for the crops exhibited the following chemical characteristics: $\mathrm{pH}=6.6$; O.M. $=39.1 \mathrm{~g} \mathrm{~kg}^{-1} ; \mathrm{N}=2.38 \mathrm{~g} \mathrm{~kg}^{-1}$; $\mathrm{P}=2.97 \mathrm{~g} \mathrm{~kg}^{-1} ; \mathrm{K}=1.75 \mathrm{cmolc} \mathrm{kg}^{-1} ; \mathrm{Ca}=9 \mathrm{cmolc} \mathrm{kg}^{-1} ; \mathrm{Mg}$ $=6.6 \mathrm{cmolc} \mathrm{kg}^{-1} ; \mathrm{Na}=1.26 \mathrm{cmolc} \mathrm{kg}^{-1} ; \mathrm{H}+\mathrm{Al}=3.3 \mathrm{cmolc}$ $\mathrm{kg}^{-1}$; and $\mathrm{Al}=0.5 \mathrm{cmolc} \mathrm{kg}^{-1}$.

The collard green seedlings were grown in 162-cell polypropylene trays. The tray cells were filled with a substrate consisting of a mixture of earthworm humus and vermiculite in the proportion of 9:1. The seedlings were kept in a screened environment ( $30 \%$ shade rate) for thirty days and then transplanted to the plant beds. radish 'Cometo' was sown directly in the plant beds on the same date as transplanting of the collard green seedlings. To prevent competition of weeds with the crops, weeds were manually removed from the plant beds each week.

Harvest of collard green began at 70 days after transplanting the seedlings (100 days after sowing - DAS) by removing the leaves that had reached the point of harvest, i.e., those with a leaf blade of at least $30 \mathrm{~cm}$. Radish 'Cometo' was harvested at 30 DAS.

The following factors were evaluated for radish 'Cometo': 1) plant height ( $\mathrm{PH})$, measured from the soil to the tip of the highest leaf; 2) shoot dry matter (SDM, kg); 3) shoot fresh matter (SFM, g); 4) root fresh matter (RFM, $\mathrm{kg}$ ); 5) root dry matter (RDM, g); 6) number of leaves (NL); 7) root diameter ( $\mathrm{D}, \mathrm{mm})$, measured with a digital caliper; 8) photosynthesis (PHS, mmol $\mathrm{cm}^{-2} \mathrm{~s}^{-1}$ ), measured in a photosynthesis analyzer, model LCi - SD, from BioScientific; and 9) "a" and "b" chlorophyll content (Chl $\mathrm{a}$; Chl b), determined by a chlorophyll meter, model CFL 1030, from Falker. 
The following variables were evaluated for collard green: 1) number of leaves (NL) suitable for harvest, beginning with weekly observation of leaves that reached a determined standard ( $\geq 30 \mathrm{~cm}$ length of the leaf blade); 2 ) leaf width (W, m); 3) leaf length (LENG, m); 4) leaf fresh matter (LFM, kg); 5) leaf dry matter (LDM, g); and 6) photosynthesis (PHS, mmol $\mathrm{cm}^{-2} \mathrm{~s}^{-1}$ ), measured in a photosynthesis analyzer, model LCi - SD, from BioScientific.

To evaluate the efficiency of intercropping compared to monoculture, the land equivalent ratio (LER) was used, which is the ratio between the area cultivated in intercropping and that cultivated in monoculture. Intercropping is considered advantageous in relation to monoculture if the LER is greater than 1.0. The LER is given by the expression:

$L E R=\frac{K i}{K m}+\frac{R i}{R m}$

where $\mathrm{Ki}$ and $\mathrm{Km}$ represent the collard green yield in intercropping and in monoculture, respectively, and $\mathrm{Ri}$ and Rm represent radish 'Cometo' yield in intercropping and in monoculture, respectively.

Analysis of variance (ANOVA) was conducted on the data obtained, and the mean values were compared by the Tukey test at $5 \%$ probability using the statistical software GENES version 1990.2018.18 (Cruz, 2013).

\section{RESULTS}

The data on shoot dry matter (SDM), shoot fresh matter (SFM), root dry matter (RDM), root fresh matter (RFM), plant height (PH), and root diameter (D) of radish 'Cometo' grown separately did not differ from the data on the other treatments (Table 1). However, if we compare radish 'Cometo' grown separately with the intercropping treatments, a slight tendency of increase in SDM (10.7\%) is observed, whereas RDM shows an opposite response, with a reduction of $13.1 \%$. For the physiological variables - photosynthesis, chlorophyll "a", and chlorophyll "b" - significant changes among the treatments were not observed, indicating that there were no relevant changes in metabolism of the plants when they were subjected to the conditions of the arrangements evaluated (Table 1).

Regarding radish 'Cometo' root diameter, no difference was observed among the treatments evaluated, and in general, all the arrangements studied were able to produce roots in the same range for mean diameter (34 mm), similar to the mean commercial standard, which is greater than 30 mm (Lee et al., 1996).

The high coefficient values of variation observed in RFM, SFM and RDM can be attributed to high sensitivity to soil water content variations, this can provide different effects, according to Silva et al. (2017), variations in soil moisture and temperature may hinder the development of this vegetable, consequently reflecting higher coefficients of variation.

For the collard green crop, there was no interaction among the factors NL, LFM, LDM, and photosynthesis. Thus, the different arrangements adopted in intercropping did not have an effect on development of the collard green crop (Table 2). In relation to leaf length and width, the mean values were similar, although these values showed a slight tendency of increase compared to collard green grown separately and to the intercropping treatments with the 2:2 and 3:2 arrangements (Table 2).

For the leaf fresh matter trait, no difference was observed among the treatments, and a mean yield of $0.84 \mathrm{t}$ $\mathrm{ha}^{-1}$ ha was observed from the four harvest times. No difference was observed among the treatments for leaf dry matter either; the treatments had a mean value of $63.20 \mathrm{~g}$ per plot (Table 2).

In regard to the land efficiency ratio (LER), adoption of intercropping proved to be advantageous, since in all the arrangements adopted, a positive ratio observed (Table 3). This suggests that an area of monoculture $16 \%, 43 \%$, and $69 \%$ greater would be necessary to obtain the same yield of commercial product compared to the arrangements evaluated.

\section{DISCUSSION}

In general, increasing crop density increases the level of competition among plants and may have an impact on yield. However, in some cases, this might not happen, especially in intercropping systems. This can be confirmed upon observing results of studies performed in diverse locations. Grangeiro et al. (2008) evaluated radish 'Cometo' yield intercropped with cilantro (Coriandrum sativum L.) and did not observe a difference between monoculture and intercropping for the variables of fresh matter and dry matter of radish 'Cometo' root. Cecílio Filho \& May (2002) observed that radish 'Cometo' plants in monoculture had an accumulation of shoot dry matter (SDM) $29.4 \%$ less than in intercropping with lettuce (Lactuca sativa L.), as well as greater accumulation of root dry matter in intercropping. Ferreira \& Cecílio Filho (2001) worked with radish 'Cometo' and carrot (Daucus carota L.) and observed that intercropping allowed greater accumulation of dry matter and fresh matter of tuber roots of radish 'Cometo' in relation to monoculture. When radish 'Cometo' is intercropped with other crops, the two species can significantly improve nutrient uptake from the soil and increase crop yield, reflecting the superiority of intercropping (Dang et al., 2012). 
The benefit of intercropping may be related to improvement in local climate conditions promoted by companion plants, which, through greater size, tend to reduce direct sunlight on the radish 'Cometo' plants in some periods of the day. Up to a certain level, reduction in direct exposure of radish 'Cometo' plants to sun can maintain the photosynthetic rate of plants high, also helping to maintain stomatal opening, which, consequently, contributes to continual assimilation of atmospheric $\mathrm{CO}_{2}$. If plants remain continuously exposed to the sun, leaf temperature may increase, resulting in higher transpiration levels through the stomata, which would stimulate stomatal closing to prevent excessive water loss. In an indirect way, such a phenomenon hinders $\mathrm{CO}_{2}$ assimilation and photosynthesis.

However, it is noteworthy that although there were different planting densities for radish 'Cometo' evaluated in this study, harvest occurred at 40 days after planting, which was before the first harvest of collard green, contributing to greater effectiveness of the 3:2 treatment (radish 'Cometo': collard green intercropping). Though the plants were intercropped, no negative effect was observed, especially in relation to light, between the two crops analyzed.
Such a situation could be expected if, at some time in the crop cycle of the intercropped plants, the leaves of the larger size crop were excessively shading the leaves of the smaller crop. Taiz \& Zaiger (2017) cite that availability of solar radiation is one of the factors that most limit plant growth and development because all energy necessary for photosynthesis to occur comes from solar radiation. In addition to competition for light, other factors affect the growth and production of crops, such as nutrients, water, and other related factors (Santos et al., 2010).

Cecílio Filho \& May (2002) also observed that radish 'Cometo' plants intercropped with lettuce had shorter plant height compared to radish 'Cometo' plants grown separately. According to the authors, there was competition between the two crops, possibly for light, which probably resulted in lower growth of the radish 'Cometo' plants.

It should be considered that the proximity of the crops in intercropping disposes plants to interspecific competition, most commonly for light, water, and nutrients (Oliveira et al., 2010).

In this study, the photosynthetic rate of the two crops was not affected by the intercropping and harvest times. Thus, there was no difference between the treatments for this variable. This information is important because it

Table 1: Shoot fresh matter - SFM, shoot dry matter - SDM, root fresh matter - RFM, root dry matter - RDM, number of leaves - NL, plant height - PH, root diameter - D, photosynthesis - PHS, chlorophyll "a" - Chl a, and chlorophyll "b" - Chl b in radish 'Cometo' (Raphanus sativus) intercropped with collard green (Brassica oleracea var. acephala) under different spatial arrangements. Fortaleza, CE, Brazil

\begin{tabular}{|c|c|c|c|c|c|c|c|c|c|c|}
\hline \multirow{2}{*}{ Treat. } & \multirow{2}{*}{$\begin{array}{c}\text { SFM } \\
(\mathrm{kg})\end{array}$} & \multirow{2}{*}{$\frac{\text { SDM }}{(\mathrm{g})}$} & \multirow{2}{*}{$\frac{\text { RFM }}{(\mathbf{k g})}$} & \multirow{2}{*}{$\frac{\text { RDM }}{(\mathrm{g})}$} & \multirow{2}{*}{ NL } & \multirow{2}{*}{$\begin{array}{l}\text { PH } \\
(\mathrm{cm})\end{array}$} & \multirow{2}{*}{$\frac{\mathrm{D}}{(\mathrm{mm})}$} & \multirow{2}{*}{$\frac{\text { PHS }}{\left(\mathrm{mmol} \mathrm{cm}^{-2} \mathrm{~s}^{-1}\right)}$} & \multirow{2}{*}{ Chl a } & \multirow{2}{*}{ Chl b } \\
\hline & & & & & & & & & & \\
\hline Single & $0.0314 \mathrm{a}$ & $1.30 \mathrm{a}$ & $0.0265 a$ & $1.60 \mathrm{a}$ & $6 a$ & $21.20 \mathrm{a}$ & $36.09 \mathrm{a}$ & $19.92 \mathrm{a}$ & $27.65 \mathrm{a}$ & $6.29 a$ \\
\hline$(1: 2)$ & $0.0177 \mathrm{a}$ & $1.25 \mathrm{a}$ & $0.0327 \mathrm{a}$ & $1.53 \mathrm{a}$ & $7 \mathrm{a}$ & $17.63 \mathrm{a}$ & $34.49 \mathrm{a}$ & $18.34 \mathrm{a}$ & $28.74 \mathrm{a}$ & $7.83 \mathrm{a}$ \\
\hline$(2: 2)$ & $0.0182 \mathrm{a}$ & $1.32 \mathrm{a}$ & $0.0308 \mathrm{a}$ & $1.59 \mathrm{a}$ & $6 a$ & $20.72 a$ & $33.61 \mathrm{a}$ & $22.47 \mathrm{a}$ & $27.18 \mathrm{a}$ & $6.77 \mathrm{a}$ \\
\hline$(3: 2)$ & $0.0221 \mathrm{a}$ & $1.44 \mathrm{a}$ & $0.0524 \mathrm{a}$ & $1.39 \mathrm{a}$ & $7 \mathrm{a}$ & $21.31 \mathrm{a}$ & $33.25 \mathrm{a}$ & $18.62 \mathrm{a}$ & $27.84 \mathrm{a}$ & $6.95 \mathrm{a}$ \\
\hline $\mathrm{CV}(\%)$ & 36.53 & 29.24 & 73.72 & 30.45 & 14.39 & 11.63 & 12.57 & 15.07 & 4.61 & 15.13 \\
\hline
\end{tabular}

Mean values followed by the same letter do not differ from each other by the Tukey test at the level of 5\% probability.

Table 2: Leaf length (LENG), leaf width (W), number of leaves (NL), leaf fresh matter (LFM), leaf dry matter (LDM), and photosynthesis (PHS) of collard green (Brassica oleracea var. acephala) intercropped with radish 'Cometo' (Raphanus sativus) under different spatial arrangements. Fortaleza, CE, Brazil

\begin{tabular}{|c|c|c|c|c|c|c|}
\hline \multirow{2}{*}{ Treat. } & LENG & $\mathbf{W}$ & \multirow{2}{*}{ NL } & LFM & LDM & PHS \\
\hline & (cm) & $(\mathrm{cm})$ & & (kg) & (g) & $\left(\mathrm{mmol} \mathrm{cm} \mathrm{c}^{-2} \mathrm{~s}^{-1}\right)$ \\
\hline Single & $21.747 \mathrm{a}$ & $18.710 \mathrm{a}$ & $7.18 \mathrm{a}$ & $0.635 \mathrm{a}$ & $56.417 \mathrm{a}$ & $24.779 \mathrm{a}$ \\
\hline$(1: 2)$ & $21.242 \mathrm{a}$ & $18.082 \mathrm{a}$ & $8.37 \mathrm{a}$ & $0.673 \mathrm{a}$ & $64.000 \mathrm{a}$ & $23.779 \mathrm{a}$ \\
\hline$(2: 2)$ & $22.965 \mathrm{a}$ & $19.482 \mathrm{a}$ & $7.31 \mathrm{a}$ & $0.757 \mathrm{a}$ & $74.038 \mathrm{a}$ & $23.796 \mathrm{a}$ \\
\hline$(3: 2)$ & $23.869 \mathrm{a}$ & $19.092 \mathrm{a}$ & $7.12 \mathrm{a}$ & $0.615 \mathrm{a}$ & $58.328 \mathrm{a}$ & $25.320 \mathrm{a}$ \\
\hline $\mathrm{CV}(\%)$ & 11.06 & 8.02 & 9.60 & 26.65 & 20.01 & 9.32 \\
\hline
\end{tabular}

Mean values followed by the same lowercase letter in the column for the spatial arrangements and uppercase letters in the column for harvest times do not differ from each other by the Tukey test at the level of 5\% probability. 
Table 3: Yield and land equivalent ratio - LER in collard green (Brassica oleracea var. acephala) intercropped with radish 'Cometo' (Raphanus sativus) under different spatial arrangements. Fortaleza, CE, Brazil

\begin{tabular}{lccc}
\hline Treat. & Collard green $\left(\mathbf{t ~ h a}^{-\mathbf{1}}\right)$ & Radish 'Cometo' $\left(\mathbf{t} \mathbf{~ h a}^{\mathbf{1}}\right)$ & LER \\
\hline Single & 25.40 & 20.67 & - \\
$(1: 2)$ & 26.92 & 2.12 & 1.16 \\
$(2: 2)$ & 30.28 & 4.92 & 1.43 \\
$(3: 2)$ & 24.60 & 14.93 & 1.69 \\
\hline
\end{tabular}

shows that the planting density of the growing systems evaluated did not cause competition for light between the two crops evaluated or within the crops grown separately.

According to Strassburger et al. (2010), the use of a suitable planting density can provide greater efficiency in use of incident solar radiation on the plant canopy and, consequently, greater production per area. Just as for photosynthetic rate, the chlorophyll "a" and "b" content also did not differ among the treatments. According to Rego \& Possamai (2006), the chlorophyll and carotenoid contents in the leaves are measured to check the photosynthetic capacity of the plants because of their direct connection with absorption and transfer of light energy and with growth and adaptation to diverse environments.

In this study, all the intercropping arrangements proved to be more efficient; the LER in all cases was greater than 1. The greater the LER, the more advantageous the intercropping system (Liebman, 2012). According to Sediyama et al. (2014), the LER quantifies the relative area necessary for monoculture production to equal the production of the same crops grown together. It is considered a practical and quite useful method for indicating the efficiency of cultivation.

Thus, the greater production obtained in the intercropping system can be explained by the principle of competitive production, in which one species generates benefits for the other. Competition between species varies according to the similarity of needs they have (Vandermeer, 1989). When there is similarity between the niches, different level of needs and a low level of competition, the species can remain in the same area (Silva \& Comin, 2013)

The radish presents a great alternative of cultivation since it can be cultivated all year round and can still be intercalated with other long cycle cultures, enabling rapid financial returns, with income obtaining during this period (Matos et al., 2015, Bonela et al., 2017).

The LER reinforces that intercropping was advantageous, because collard green was not affected by radish 'Cometo'. Intercropping provided additional production in the arrangements adopted, improving cropping practices.

\section{CONCLUSIONS}

The spatial arrangements adopted did not affect the individual growth and development of the radish 'Cometo' and collard green plants. The most recommended intercropping arrangement is $3: 2$, i.e., three rows of radish 'Cometo' between two rows of collard green, since it provides better use of the area without loss to the crops involved.

\section{ACKNOWLEDGMENTS}

Our thanks to the Conselho Nacional de Desenvolvimento Científico e Tecnológico (CNPq) and to the Coordenação de Aperfeiçoamento de Pessoal de Nível Superior (CAPES) for granting scholarships to the participants in this study.

The authors declare that there is no conflict of interest.

\section{REFERENCES}

Bonela GD, Santos WP, Sobrinho EA \& Gomes EJC (2017) Produtividade e qualidade de raízes de rabanete cultivadas sob diferentes fontes residuais de matéria orgânica. Revista Brasileira de Agropecuária Sustentável, 7:66-74.

Camili EC, Azevedo CCBV, Bocuti ED, Silvério JM, Barros KC, Silva ARB \& Seabra Júnior S (2013) Cultivo consorciado de alface sob diferentes arranjos espaciais e manejo do dossel de taioba. Revista Agrarian, 06:110-120.

Cecílio Filho AB \& May A (2002) Produtividade das culturas de alface e rabanete em função da época de estabelecimento do consórcio. Horticultura Brasileira, 20:501-504.

Cruz CD (2013) GENES - a software package for analysis in experimental statistics and quantitative genetics. Acta Scientiarum, $35: 271-276$.

Dang XY, Liu JG, Pani GL, Wang JL, Wei CZ \& LI L (2012) Uptake and conversion efficiencies of NPK and corresponding contribution to yield advantage in cotton-based intercropping systems. Chinese Journal of Eco-Agriculture, 20:513-519.

Favacho FS (2015) Eficiência agroeconômica do consórcio cenoura $\mathrm{x}$ caupi-hortaliça em função de quantidades de biomassa de flor-de-seda e arranjos espaciais. Tese de Doutorado. Universidade Federal Rural do Semiárido, Mossoró. 73p.

Ferreira RP \& Cecílio Filho AB (2001) Rendimento de raízes tuberosas de cenoura e rabanete em cultivo consorciado. Horticultura Brasileira, 19:01-04.

Grangeiro LC, Negreiros MZ, Santos AP, Costa LM, Silva ARC \& Lucena RRM (2008) Crescimento e produtividade de coentro e rabanete em função da época de estabelecimento do consorcio. Ciência e Agrotecnologia, 32:55-60 
Lee JM, Yoo IO \& Min BH (1996) Effect of cultivars and cultural conditions on the pungent principle contents in radish roots. Journal of the Korean Society for Horticultural Science, 37:349356 .

Li C, He X, Zhu S, Zhou H, Wang Y, Li Y, Yang J, Fan J, Yang J, Wang G, Long Y, Xu J, Tang Y, Zhao G, Yang J, Liu L, Sun Y, Xie Y, Wang H \& Zhu Y (2009) Crop Diversity for Yield Increase. Plos One, 04: e8049.

Lin L, Liu Q, Shi J, Sun J, Liao M \& Mei L (2014) Intercropping different varieties of radish can increase cadmium accumulation in radish. Environmental Toxicology and Chemistry, 33:19501955.

Liebman M (2012) Sistemas de policultivos. In: Altieri M (Ed.) Agroecologia: bases científicas para uma agricultura sustentável. $3^{\mathrm{a}} \mathrm{ed}$. Rio de Janeiro, AS-PTA. p. 221-240.

Lithourgidis AS, Dordas CA, Damalas CA \& Vlachostergios DN (2011) Annual intercrops: an alternative pathway for sustainable agriculture. Australian Journal of Crop Science, 05:396-410.

Matos RM, Silva PF \& Lima SC (2015) Partição de assimilados em plantas de rabanete em função da qualidade da água de irrigação. Journal of Agronomic Sciences, 4:151-164.

Oliveira EQ, Sousa RJ, Cruz MCM, Marques VB \& França AC (2010) Produtividade de alface e rúcula, em sistema consorciado, sob adubação orgânica e mineral. Horticultura Brasileira, 28:36-40.

Rego GM \& Possamai E (2006) Efeito do sombreamento sobre o teor de clorofila e crescimento inicial do jequitibá rosa. Boletim de Pesquisa Florestal, 53:179-194.

Rezende BLA, Cecílio Filho AB, Feltrim AL, Costa CC \& Barbosa JC (2006) Viabilidade da consorciação de pimentão com repolho, rúcula, alface e rabanete. Horticultura Brasileira, 24:36-41.
Rezende BLA (2008) Consórcio de pepino e alface em cultivo protegido: viabilidade agroeconômica. Tese de Doutorado. Universidade Estadual Paulista Júlio de Mesquita Filho, Jaboticabal. $163 \mathrm{p}$.

Resende FL \& Vidal MC (2008) Organização da propriedade no sistema orgânico de produção. Brasília, Embrapa Hortaliças. 11p. (Circular Técnica, 63).

Santos NCB, Arf O \& Komuro LK (2010) Consórcio de feijoeiro e milho-verde na entressafra-I comportamento das cultivares de feijão. Bioscience Journal, 26:865-872.

Sediyama MAN, Santos IC \& Lima PC (2014) Cultivo de hortaliças no sistema orgânico. Revista Ceres, 61:829-837.

Silva JCBV \& Comin JJ (2013) Desempenho agronômico de milho, feijão, soja e abóbora em sistema orgânico de monocultivo e consórcio. Revista Brasileira de Agroecologia, 08:191-199.

Silva AFA, Souza EGF, Barros Júnior AP, Bezerra Neto F \& Silveira LM (2017) Desempenho agronômico do rabanete adubado com Calotropis procera (Ait.) R. Br. em duas épocas de cultivo. Revista Ciência Agronômica, 48:328-336.

Strassburger AS, Peil RMN, Schwengber JE, Medeiros CAB, Martins DS \& Silva JB (2010) Crescimento e produtividade de cultivares de morangueiro de "dia neutro" em diferentes densidades de plantio em sistema de cultivo orgânico. Bragantia, 69:623-630.

Taiz L \& Zeiger E (2017) Fisiologia Vegetal. 6 ${ }^{\mathrm{a}}$ ed. Porto Alegre, ARTMED. 888p.

Vandermeer J (1989) The ecology of intercropping. Cambridge, Cambridge University Press. 237p. 